\title{
Colusite from the Plavitsa gold deposit - a new mineral for the Republic of North Macedonia
}

\section{Колусит от златорудното находище Плавица - нов минерал за Република Северна Македония}

\section{Gotse Zlatkov \\ Гоце Златков}

Genesis Resources International DOOEL, Skopje, Republic of North Macedonia; E-mail: gzlatkov@yahoo.com

\begin{abstract}
The Plavitsa ore deposit is a part of the Zletovo ore field. Two ore zones were established: primary (sulphide) and secondary (oxide, gold-bearing). The colusite occurs at the primary sulphide ore zone. The results of the microprobe analyses in wt\%: Cu 47.38, V 3.41, Sn 8.28, As 10.75, Sb 2.01, Fe 0.11, S 29.1. LA-ICP-MS revealed contents of Te, Se, In, Ag, and Au. The micro-hardness (H) is $280-310 \mathrm{~kg} / \mathrm{mm}^{2}$. At $\lambda 540$ and $580 \mathrm{~nm} \mathrm{R}$ is $29 \%$ and $29.6 \%$. The colusite associates with enargite, famatinite, luzonite, bornite, barite, tennantite, tetrahedrite and tellurides of $\mathrm{Au}$ and $\mathrm{Ag}$.
\end{abstract}

Keywords: Plavitsa, Sn, V, assemblage, Kratovo-Zletovo volcanic region.

\section{Introduction}

The Plavitsa gold ore deposit is located in the Zletovo ore field in the central part of the KratovoZletovo volcanic region. Two mineral-geochemical ore zones are defined in the deposit - primary (sulphide) and secondary (oxide) with economically significant concentrations of gold (Fig. 1).

\section{Brief geological setting}

The Plavitsa deposit is located in Tertiary volcanic-sedimentary rocks: andesitic fine-grained and coarse-grained tuffs, laminated ash tuffs and andesitic lapilli tuffs, covered with a cap of cavernous secondary quartzites. Due to the influence of hypergene factors within and under the cavernous quartzites, intensive oxidation processes have taken place, which locally acted down to $200 \mathrm{~m}$ depth. Late Oligocene $(27 \mathrm{Ma}){ }^{40} \mathrm{~K} /{ }^{40} \mathrm{Ar}$ age is obtained for the hosting biotite andesites and dacites (Alderton, Serafimovski, 2007). ${ }^{40} \mathrm{~K} /{ }^{40} \mathrm{Ar}$ age of $30.5-33.5 \pm 0.5 \mathrm{Ma}$ is obtained for the Tertiary rocks from the Kratovo-Zletovo volcanic region (Boev, Yanev, 2001). Similar early Oligocene U-Pb zircon age of 32.26-
$33.56 \pm 0.25 \mathrm{Ma}$ is obtained from small- to largeporphyry latites, exposed along the upper course of Petroshnitsa River in the northwestern flank of the same area (Mankov et al., 2016). ${ }^{40} \mathrm{Ar} /{ }^{39} \mathrm{Ar}$ ages of $25.50-25.83 \pm 0.40 \mathrm{Ma}$ are defined using the analysis of alunite in the host rocks of the deposit. The ore mineralization postdated late Oligocene and is younger than $25 \mathrm{Ma}$.

\section{Source material and research methods}

For the purposes of the study, 45 ore-rock samples of drilling cores crossing the oxide and sulphide ore zones were taken -30 from the primary sulphide zone and 15 from the oxide one. They were examined under a microscope in reflected vertical and oblique light - Amplival, pol D. The micro-hardness of the established colusite was determined using a PMT-3 device in University of Mining and Geology "St. Ivan Rilski", Sofia. The reflection spectra were measured on a NU-2 microscope with a sliding monochromator with an NF photodetector (in University of Mining and Geology "St. Ivan Rilski", Sofia), the chemistry was measured through a microprobe analysis (JEOL, JSM 35 CF-EDS-NO- 


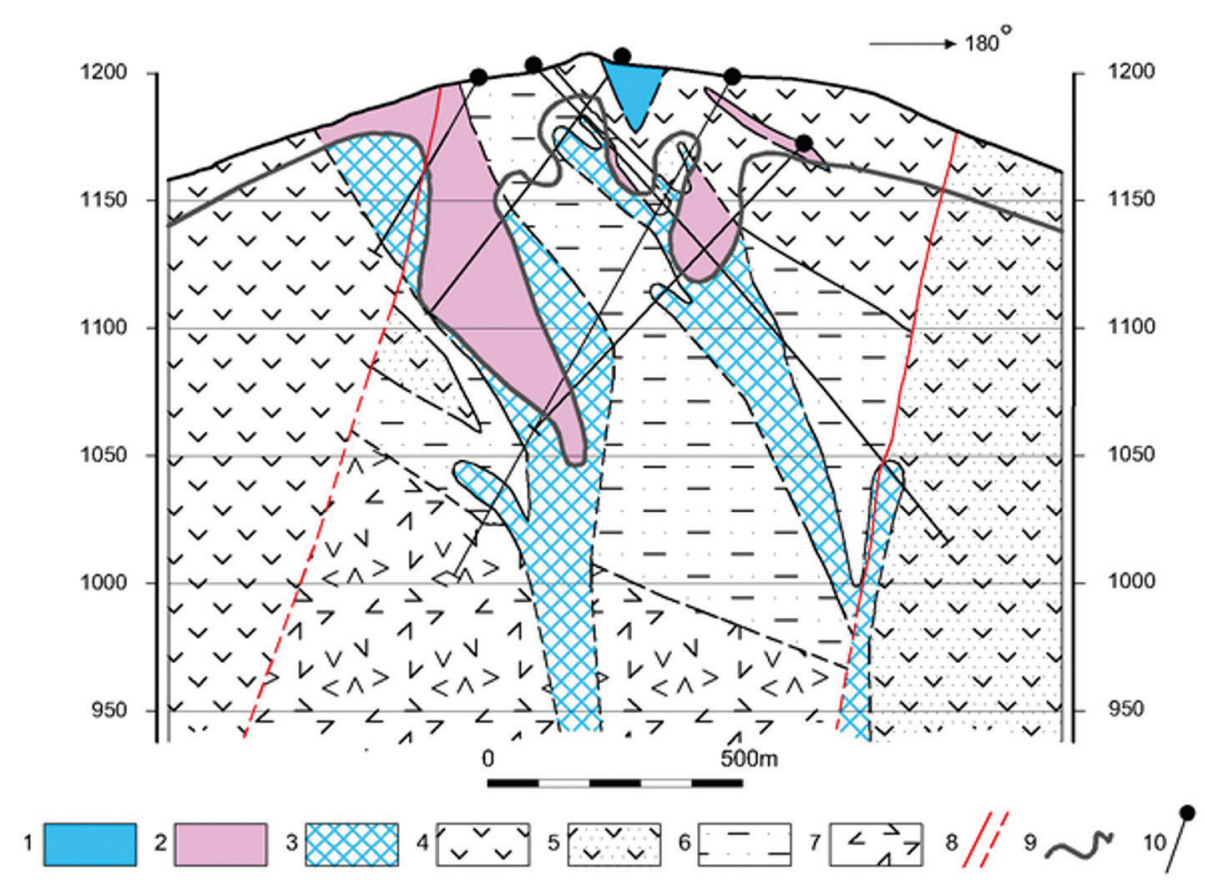

Fig. 1. The Plavitsa deposit, Republic of North Macedonia - geological cross-section: 1, cavernous quartzites; 2, oxide goldbearing zone; 3 , sulphide ore zone; 4 , andesitic fine tuffs; 5 , andesitic coarse tuffs; 6 , stratified ash tuffs; 7 , andesite lapilli tuffs; 8 , traced and assumed fault; 9 , lower boundary of the oxidized zone; 10 , exploratory drilling

RAN) - Eurotest-Control SA, Sofia and laser ablation (LA-ICP-MS) - Geological Institute, Bulgarian Academy of Science, Sofia.

\section{Mineral paragenesis}

The colusite in the deposit is established in the central part of the primary sulphide ore zone, located below the level of the lower limit of the oxidation processes and controlled by clearly defined fault structures (Fig. 1). It participates in the main quartz-chalcopyrite-enargite assemblage, which is the main sulphide assemblage in the deposit, carrier of the copper concentrations and part of the concentrations of $\mathrm{Au}, \mathrm{Ag}, \mathrm{Se}$, and Te. Besides colusite, the deposit contains quartz, pyrite, enargite, chalcopyrite, bornite, chalcocite, luzonite, famatinite, gold, native $\mathrm{Ag}$, Au-bearing $\mathrm{Ag}$, and $\mathrm{Au}$ tellurides (also hessite, petzite, calaverite, krenneriteraneite, nagyagite and calcite).

\section{Description of the colusite}

Tin-vanadium sulfides of copper are considered as very rare minerals in the ore deposits. The optical and the other physical properties of the colusite from these assemblages are very close to the $\mathrm{Cu}$-As sulphide and sulfosalt minerals, as well as to the minerals from the tenanthite-tetrahedrite series. Therefore, the colusite is often not distinguished in the ordinary ore microscopic examinations in reflected light. It is a typical mineral of the deeper levels of the vein-lenticular-nestlike pyrite-enargite-tetrahedrite-tennantite ore bodies of the primary sulphide zone and of the propylitization zones with disseminated sulphide mineralization. It is associated with pyrite, enargite, famatinite, luzonite, bornite, chalcocite, chalcopyrite and a number of $\mathrm{Ag}, \mathrm{Ag}-\mathrm{Au}$ and $\mathrm{Au}$ tellurides. It appears as allotriomorphic to hypidiomorphic granules or rings around enargiteluzonite-famatinite grains. In reflected light, it is isotropic, grayish-white with a slightly brownish to yellow-brownish tinge, close to the color of the minerals from the tenanthite-tetrahedral series and to chalcocite. Its micro-hardness is lower than that of tennantite tetrahedrite $\left(280-310 \mathrm{~kg} / \mathrm{mm}^{2}\right)$. At $\lambda 500$, 540 and $580 \mathrm{~nm}$, the measured reflection R (\%) is 28.6, 29.0, and 29.6, respectively. The microprobe analyzes of two different mineral grains of colusite, optically homogeneous in reflected light, show that the average concentrations of the elements (in wt $\%$ ) of both analyzes are: $\mathrm{Cu} 47.38, \mathrm{~V} \mathrm{3.41,} \mathrm{Sn} \mathrm{8.28,}$ As 10.75, Sb 2.01, Fe 0.11, and S 29.1. Using the method of laser ablation (LA-ICP-MS), in addition to the main formula-forming elements, a number of impurity elements were found in the colusite (in ppm): Te 283-1066, Se 121-343, In 233.62-264.55, and $\mathrm{Ag}$ 56.20-120.01, also unevenly distributed high concentrations of Au from $3.35 \mathrm{~g} / \mathrm{t}$ to $10.15 \mathrm{~g} / \mathrm{t}$. 


\section{Discussion of the results}

The elements Sn and V are typomorphic elements for the Tertiary deposits from the western flank of the Rhodope Massif on its border with the Vardar zone - here are the Tertiary deposits from the ore belts Osogovo-Besna Kobila (Mankov, 1974, 1988) and Lece-Halkidiki (referred to as the "ore zone"; Janković, 1967; Serafimovski, 1993).

We associate the appearance of tin in the Plavitsa deposit with the intensive pneumatolytic-hydrothermal processing of the lithospheric blocks in connection with the subduction of the Vardar zone and with the Tertiary magmatism. The vanadium concentrations are probably related to the regeneration of ultramafic and granodioritic magmatic rocks, located to the east of the Vardar zone and in the depths of the Kratovo-Zletovo volcanic region.

The qualitative composition of the Plavitsa colusite is close to stibiocolusite (Spiridonov et al., 1992), however, it differs from it in quantitative terms - its formula-forming elements are characterized by a certain unevenness, but the real crystal chemical formula is close to the $\mathrm{Cu}_{3} \mathrm{XS}_{4}$ formula proposed by Levy (1967) and to the real formula of the colusite from the porphyry-copper Medet deposit (Strashimirov, 1982).

The obtained LA-ICP-MS data provide additional information on the microchemistry of the colusite. The established impurity elements such as $\mathrm{Se}, \mathrm{Te}, \mathrm{In}, \mathrm{Au}, \mathrm{Ag}$ are associated with both the phenomena of isomorphism and microscopic mechanical inclusions of various mineral forms of $\mathrm{Ag}-\mathrm{Te}, \mathrm{Ag}, \mathrm{Ag}-\mathrm{Au}$, and $\mathrm{Au}$ tellurides. The association of colusite includes mainly minerals of the $\mathrm{Cu}$ sulphides and sulfosalts, and of the $\mathrm{Cu} \mathrm{As}-\mathrm{Sb}$ sulfosalts - enargite, famatinite, luzonite, bornite, barite, chalcocite, tennatite-tetrahedrite, freibergite hessite, calaverite, krennerite, sylvanite and others, belonging to the volcanic epitermal high-sulfidation type of mineralizations, associated with the crust magmatism.

Acknowledgments: The author expresses his gratitude to Assist. Prof. D. Dimitrova from the Bulgarian Academy of Sciences for the performed LA-ICP-MS analyzes of the colusite.

\section{Reference}

Alderton, H. M. D., T. Serafimovski. 2007. The geology and genesis of the Plavica copper-gold deposit, Macedonia. Applied Earth Sci. (Trans. Inst. Min. Metall. B), 116, 2, 94-105; https://doi.org/10.1179/174327507X167073.

Boev, B., Y. Yanev, 2001. Tertiary magmatism within the Republic of Macedonia: a review. - Acta Vulcanol., 13, 1-2, $57-71$.

Janković, S. 1967. Metallogenetic Epochs and Ore-bearing Areas of Yugoslavia. Belgrade, Prosveta-Poiarevac, 202 p. (in Serbian).

Levy, C. 1967. Contribution à la minéralogie des sulfures de cuivre du type $\mathrm{Cu}_{3} \mathrm{XS}_{4}$. - Mém. Bureau Rech. Géol. Minières., 54, 528-533.

Mankov, S. 1974. Systematics of mineralization associated with Tertiary magmatism of the Ruen ore field, Bulgaria. - Problems of Ore Formation, IV Symposium, JAGOD. Varna, 1, 157-162 (in Russian).

Mankov, S. 1988. Ruen ore field. - In: Lead-Zinc Deposits in Bulgaria. Sofia, Technika, 90-114 (in Bugarian).

Mankov, S., M. Antonov, D. Siroshtan, V. Grozdev, 2016. New data on Cenozoic volcanism and ore mineralizations in the Petroshnitsa river valley, NW part of the Kratovo-Zletovo volcanic area, Republic of Macedonia. - Third Congress of Geologists of Republic of Macedonia, 3, 589-597.

Serafimovski, T. 1993. Structural-metallogenetic Characteristics of the Lecce-Halkidiki Area: Types of Deposits and Zoning. 2nd spec. ed., 235 p. (in Macedonian).

Spiridonov, E., A. Badalov, V. Kovachev. 1992. Stibiocolusit $\mathrm{Cu}_{26} \mathrm{~V}_{2}(\mathrm{Sb}, \mathrm{Sn}, \mathrm{As})_{6} \mathrm{~S}_{32}$ - a new mineral. - Dokladi Acad. Nauk SSSR, 324, 2, 411-414 p. (in Russian).

Strashimirov, S. 1982. Sulvanite and colusite from the molybdenum-copper deposit Medet. - Geochem., Mineral. and Petrol., 15, 57-66 (in Bulgarian with English abstract). 